\title{
Narrative coherence in Digenes Akrites (G)*
}

\author{
Markéta Kulhánková \\ Masaryk University, Brno \\ mkulhanko@phil.muni.cz
}

This article argues that coherence in medieval narratives was perceived differently than it is in modern literature, offering an analysis of coherence principles in Digenes Akrites which seem to have been more relevant for its original audiences. Drawing on contemporary narratology and recent research on comparable western works, the author does not search for one sole superordinate principle, but rather for so-called structures of mid-range coherence. The article contains some examples of such 'centres of gravity' - the schema, the scene and the meaning - in the G version.

Keywords: Digenes Akrites; Byzantine narrative poetry; coherence structures; plot logic; medieval narratology

Scholarship on the Digenes Akrites poem is rich, especially as regards its origins, the relations between the different versions, its oral background and historical context, its genre, and its connections to other literary works. Several interpretations have been advanced - more often of individual passages than of the whole work. ${ }^{1}$ The dispute about the priority between the Escorial and the Grottaferrata versions (hereafter E and G)

* This study is a result of the project 'A Narratological commentary on Digenes Akrites' funded by the Czech Science Foundation (19-05387S). I would like to express my gratitude to the two anonymous readers who reviewed my text for $B M G S$. Their valuable remarks and suggestions not only helped me to improve the present article, but also provided new and inspiring impulses for my future work.

1 Some examples, which will also be discussed below, are the psychoanalytical reading of the dragon slaying scene: C. Livanos, 'A case study in Byzantine dragon-slaying: Digenes and the Serpent', Oral Tradition 26 (2011) 125-44; the analysis of the character of Maximou: D. Ricks, 'Maximou's metamorphoses', in J.-M. Egea and J. Alonso (eds.), Prosa y verso en griego medieval (Amsterdam 1996) 319-28; or A. R. Dyck's analyses of three books of G: 'On Digenis Akritas, Grottaferrata version, Book 5'; 'On Digenes Akrites, Grottaferrata version, Book 6'; and 'The taming of Digenes: the plan of Digenes Akrites, Grottaferrata Version, Book 4', all in Greek, Roman and Byzantine Studies 24 (1983) 185-92, 28 (1987) 349-69 and 35 (1994) 293-308 respectively.

(C) The Author(s), 2021. Published by Cambridge University Press on behalf of Centre for Byzantine, Ottoman and Modern Greek Studies, University of Birmingham. This is an Open Access article, distributed under the terms of the Creative Commons Attribution licence (http://creativecommons.org/licenses/by/4.0/), which permits unrestricted re-use, distribution, and reproduction in any medium, provided the original work is properly cited.

DOI: $10.1017 /$ byz.2021.14 
has employed scholars for many decades. Despite all this demanding and valuable scholarly work, our understanding of this peculiar literary monument of the Byzantine world is still limited.

While exploring the qualities of the different versions and their closeness to the supposed original text, scholars have also discussed the work's literary coherence. Some considered the $G$ version more successful in this respect; thus, Elizabeth Jeffreys has claimed that ' $G$ presents a relatively coherent narrative', ${ }^{2}$ while 'redactors of the $\mathrm{E}$ version attempted to impose a more accurate vernacular syntax but were less concerned with coherence of the plot'. ${ }^{3}$ On the other hand, according to Andrew R. Dyck, the redactor of $G$ 'had literary ambition and was interested in moral questions but paid too little attention to coherence of plot'. ${ }^{4}$ Stylianos Alexiou, the leading scholar in favour of the $\mathrm{E}$ version, who denounced $\mathrm{G}$ mercilessly as a bad work of literature in many aspects, reproached it because, according to him, the summary of the first three books at the beginning of the fourth book (4.37-62) does not make sense, the division into books contradicts the organic structure of the narrative, and the first-person narration in Books 5 and 6 are not coherent with the remaining parts. ${ }^{5}$ Special mention may be made of Bernard Fenik's analysis of the narrative technique of E, based on the study of single episodes and showing that they are composed according to traditional epic patterns to be found both in Homer and in Western vernacular epic. As for G, Fenik argued that it is far removed from this epic style. ${ }^{6}$

None of the scholars commenting on the coherence in Digenes felt any need to deal with the question of what makes a literary text coherent. Is coherence really an objective, constant and generally accepted quality that stands in no need of explanation or clarification? In his survey of the narratological study of coherence (focused on modern literature), Michael Toolan has pointed out that 'perhaps more than anything else, narratological studies of coherence highlight the insufficiency of a "common sense" approach to the issue. ${ }^{7}$ And this, I would say, is particularly true when we deal with literary texts written centuries ago.

Here I will discuss principles and qualities other than congruity and consistency of plot, characteristics which could have made Digenes coherent in the eyes of its

2 E. M. Jeffreys, 'Maximou and Digenis', Byzantinoslavica 56 (1995) 367-74 (367).

3 Jeffreys, 'Maximou and Digenis', 347. Cf. also E. M. Jeffreys (ed.), Digenis Akritis (Cambridge 1998), xxvi.

4 Dyck, 'On Digenes Akrites, Book 6', 369.

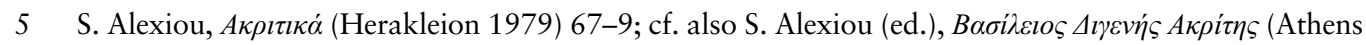
1985/2006), $x \alpha^{\prime}-\rho \beta^{\prime}$. See also A. J. Goldwyn and I. Nilsson, 'Troy in Byzantine romances: Homeric reception in Digenis Akritis, the Tale of Achilles and the Tale of Troy', in Goldwyn and Nilsson (eds.), Reading the Late Byzantine Romance: a handbook (Cambridge 2019), 188-210 (194-195), arguing that the use of first-person narration stands firmly within the Greek tradition of both romance and epic.

6 B. Fenik, Digenis: epic and popular style in the Escorial version (Herakleion 1991), see esp. 71-5.

7 M. Toolan, 'Coherence', in P. Hühn et al. (eds.), The Living Handbook of Narratology (Hamburg 2013) $\mathbb{\$}$ 3, http://www.lhn.uni-hamburg.de/article/coherence [accessed 2 May 2021]. 
contemporary recipients. I will focus on the $\mathrm{G}$ version and I wish to show that, although G might be remote from the oral tradition-based 'epic' style that Fenik showed for E, it follows rules and principles of composition and coherence more broadly valid for contemporary works of literature. A look beyond Byzantium, revealing that many of the peculiarities that create issues for us with Digenes $G$ occur also in comparable works of medieval western literatures, will help with this goal. Studies by narratologists dealing with such texts have shown that it is a different perception of coherence of a literary work in the Middle Ages that stands behind these peculiarities, rather than incapacity on the part of the authors or redactors. ${ }^{8}$

\section{The $G$ version: discrepancies, gaps, contradictions}

It can be inferred from Dyck's remarks on the 'coherence of plot' in $G$ that he understands coherence in a very modern sense, as a logical, clear, reasonable and consistent succession of narrated events. ${ }^{9}$ Let us look at some illustrative examples of inconsistencies drawn from the episode narrating Digenes' confrontation with the raiders (apelatai, G 6.11558). ${ }^{10}$ Jeffreys notes that this passage points to 'the incoherent nature of the poem's raw material'. ${ }^{11}$ First, there is serious disagreement about the number of the raiders. In 6.116-22, three apelatai emerge, indicated by their names Ioannakes, Philopappous and Kinnamos (and Digenes, the narrator of this passage, clarifies that he learned their names only later). They hear the sweet voice of Digenes' Girl, and on coming closer and seeing her beauty are 'moved to boundless passion'. Here, suddenly, the narrator

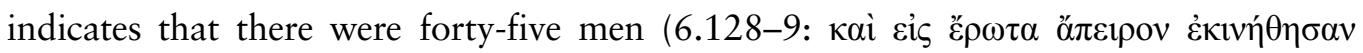

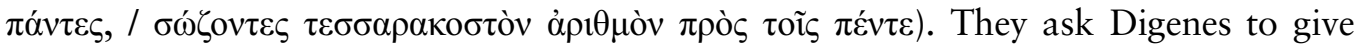
them the Girl, which he refuses, and in the ensuing fight he kills all of them (6.156: кai

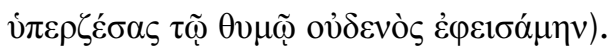

Nevertheless, in 6.176 Ioannakes, Kinnamos and Philopappous emerge again, searching for their men, as if they had not taken part in the previous battle and were not even aware of it. Moreover, although this passage states that Ioannakes, Kinnamos and Philopappous had lost all of their men (cf. also 6.363), later, at 6.450, Ioannakes

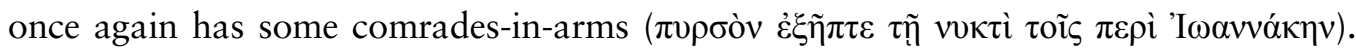
Finally, in 6.549, suddenly and without any explanation, emerges a fourth eponymous apelates, Leandros. Other discrepancies can be observed in various details. For example, in his very first battle with the raiders, Digenes first grasps his staff (6.144:

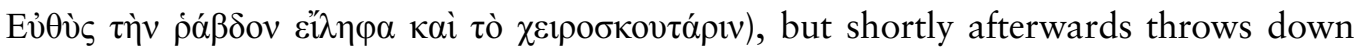

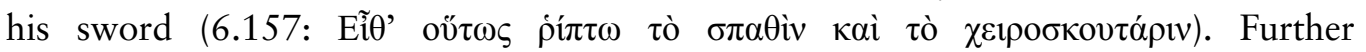

8 Similarly, Fenik studied the epic patterns of E against the background of his previous work on Homer and Nibelungenlied; see B. Fenik, Homer and the Nibelungenlied: comparative studies in epic style (Cambridge 1986).

9 Cf. Toolan, 'Coherence', $\mathbb{} 1$.

10 Here and throughout from the edition by E. Jeffreys, Digenis Akritis.

11 Jeffreys, Digenis Akritis, 159. 
contradictions concern the setting: while the plot of Book 6 is repeatedly set by a spring (cf. 6.19, 45, 60-1), suddenly and without any indication, the characters move around a river (6.171).

The last example, also from Book 6, does not contain manifest inconsistencies like those just listed, but still seems contradictory in terms of plot logic. At 6.581-95, the first clash of Digenes and Maximou is narrated: Digenes breaks her spear and spares her, but shows her his strength by cutting off her horse's head. Maximou, overwhelmed with terror (6.590), falls at his feet (6.591), begs for mercy and

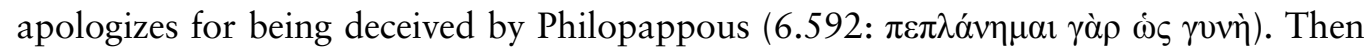
Digenes offers her an edifying speech (6.645-50) and she resolutely acknowledges his superiority, both through gestures $(6.651-3,666-7)$ and through words (6.656665.668-670), but then, surprisingly enough, she suggests further combat (6.671-7). This takes place the next day and ends with the second defeat of Maximou and sex between the two fighters. Except for this outcome, the passage displays many similarities with the first combat scene: Digenes is touched by her beauty (6.594 and 6.757), spares her and demonstrates his power by slaying her horse (6.588 and 6.7603), her fright is described in similar wording (6.591: $\dot{\eta} \delta \dot{\varepsilon} \alpha \dot{\alpha} v \alpha \pi \circ \delta i ́ \sigma \alpha \sigma \alpha, \tau \rho o ́ \mu \omega$

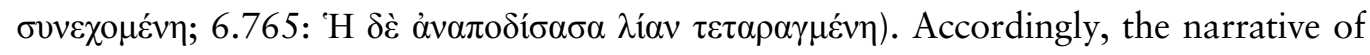
the second combat can well generate the impression that it is repetitive: that originally there was only one instance of combat and that the double narration is a result of the confusion of two versions of a single event. ${ }^{12}$

\section{Western vernacular narratives: coherence models and centres of gravity}

Parallels and similarities between Digenes and roughly contemporary western heroic poetry (such as the Nibelungenlied, the Old French chansons de geste, and the Old Spanish Cantar de Mio Cid) have been pointed out several times. ${ }^{13}$ Recently, even direct influence from this type of literature on Digenes has been suggested. ${ }^{14}$ This suggestion deserves further discussion and research beyond the scope of this article, but the generic and typological parallels are strong enough. Other strikingly similar features include the coherence problems occurring in both Digenes and its western

12 I use the term 'repetitive' in the sense of G. Genette, Narrative Discourse (Ithaca, NY 1980) 115: 'narrating $\mathrm{n}$ times what happened once'. For an attempt to analyse the sources and the 'mistakes' by the redactor in this episode, see Dyck, 'On Digenes Akrites, Book 6', 358-67. For a comparative reading of the Maximou episode in all versions, see Jeffreys, 'Maximou and Digenis' and Ricks, 'Maximou's metamorphoses'.

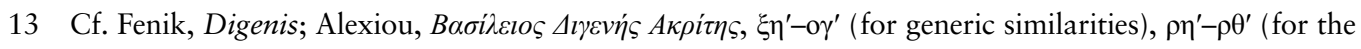
oral background), and $\rho \kappa^{\prime}-\rho \kappa \alpha^{\prime}$ (for possible echoes of Digenis in the West); E. M. Jeffreys, 'The Comnenian background to the romans d'antiquité', Byzantion 50 (1980) 455-86 (484-6). For a thematic comparative study of western and eastern heroic poetry, see C. R. Fee, Mythology in the Middle Ages (Santa Barbara 2011), with 73-101 on Digenis, and Livanos, 'A case study in Byzantine dragon-slaying'. 14 J. Trilling, 'Re-introducing Digenis Akritis: a Byzantine poem of strength, weakness, and the disturbing absence of God', Viator 47 (2017) 149-70. 
counterparts: an apparent lack of logic and consistency in the plot design, more remarkable in the less elaborated texts and those under stronger oral influence. ${ }^{15}$ Disagreements, gaps and contradictions are especially noticeable in literary works which had become widely disseminated; and so it seems that what we, from the modern point of view, perceive as incoherence was not perceived as such by the medieval audience. ${ }^{16}$ Accordingly, Christian Schneider, who has recently attempted to summarize and advance the study of coherence pursued by medievalists, aptly asks: How does a narrative, which is oriented not on the whole, but on particular bonds and partial structures of various scopes, organize coherence in respect to its content and theme? ${ }^{17}$

Schneider presents two larger groups of models for alternative approaches to achieving coherence in pre-modern narrative, elaborated in historical narratology, mostly by scholars dealing with German material. Models in the first group are based on plot logic and scholars work within the frame of these models primarily with the study of plot motivation, more precisely with the fact that in medieval narratives causal-proactive motivation is not the only, nor the dominant, motivation. Of the various alternative types of motivation, a prominent example is final-retroactive (Motivation von hinten). ${ }^{18}$ An example of this type of motivation in Digenes $\mathrm{G}$ is, for instance, the passage from Book 4 where Digenes, returning from his first hunt, approaches the palace of the general, the father of his future wife, and without knowing whose house he sees, starts singing a love song (4.254-8).

Another principle for linking the various elements together in medieval narratives is metonymic narrative (metonymisches Erzählen): a way of constructing a narrative where consecutive scenes are not connected through the relations of cause and consequence or any other type of motivation, but, similar to the trope of metonymy, through factual, spatial and temporal connection or contiguity (Kontiguität). ${ }^{19}$ For an example from Digenes G, we can turn to the end of Book 5 and the beginning of Book 6: it was April when Digenes decided to move his home at the end of Book 5 (5.282-9), so Book 6 begins with Digenes' short encomium on the month of May

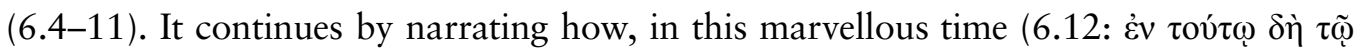

15 Several illustrative examples are offered by J. A. Schulz, 'The coherence of Middle High German narrative', in A. Classen (ed.), Medieval German Literature (Göppingen 1989) 75-86.

16 C. Schneider, 'Handlung und Handlungslogik - Mittelalter', in E. von Contzen and S. Tilg (eds.), Handbuch historische Narratologie (Berlin 2019) 249-61 (254).

17 Schneider, 'Handlung und Handlugslogik', 255: "Wie organisiert ein Erzählen, das nicht an Ganzheit, sondern an partikularen Bindungen und Teilstrukturen unterschiedlicher Reichweite ausgerichtet ist, Kohärenz inhaltlich-thematisch?"

18 Cf. e.g. J. A. Schultz, 'Why do Tristan and Isolde leave for the woods? Narrative motivation and narrative coherence in Eilhart von Oberg and Gottfired von Strassburg', Modern Language Notes 102 (1987) 586-607. For the final-retroaktive motivation see esp. C. Lugowski, Die Form der Individualität im Roman. Studien zur inneren Struktur der frühen deutschen Prosaerzählung (Berlin 1932).

19 See A. Schulz, Erzähltheorie in meidävistischer Perspektive (Berlin 2012) 333-43, with bibliography. 


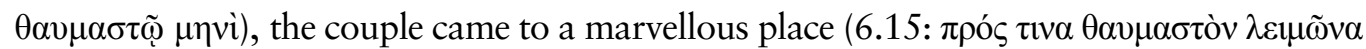

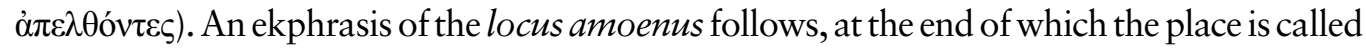
paradise (6.18-41). The ekphrasis includes singing birds and ends with a description of scents. Singing birds and scent form a bridge to the following narration that features Digenes sleeping on his bed, being sprinkled with rosewater and surrounded by singing birds (6.42-4). The Girl, after sprinkling Digenes with rosewater, goes to the spring and sprinkles her own feet with water (6.46) and thereupon the image of the paradise is completed with emerging of the serpent/dragon (6.47-8). This series of actions is connected not by causality, but by contiguity first of time, then of space, then of the senses and finally on extratextual common ideas (connection of paradise and the serpent).

The models in the second group, according to Schneider, are based on semantic logic. These models suggest that in various (not only medieval) types of narratives, paradigmatic relations (the relations between the whole and the parts) have a stronger impact on the organization of the narrative than syntagmatic ones (the mutual relations among the individual parts). In other words, in medieval narratives the linking between individual parts is for them less important than the linking of the individual parts to the whole. ${ }^{20}$ In such texts, the perception of narrative coherence derives from repetitive relationships (Wiederholungsbeziehungen), comparability and functional equivalence (funktionale Äquivalenz) of different sections, and cata- and anaphoric relationships among the elements of the narrative. This type of narrative typically includes episodicity, chaining and repetition with variation. ${ }^{21}$ In Digenes G, one thinks, for instance, of the five variants of the motif of the abduction of a girl, all pointing to the overall aim of elaborating the nuances of the relationship and symmetry (or lack of it) between man and woman (see below). This group of models can in my view also include contradiction perceived as narrative principle, or a narrative presented as a conflict between competing principles. ${ }^{22} \mathrm{~A}$ representative example of this logic as regards Digenes can be seen in Catia Galatariotou's unique attempt to interpret $G$ as a narrative construction built around a series of structural oppositions, such as house and tent, the emperor and Digenes, honour and shame, male and female. According to Galatariotou, these structural oppositions underscore the crucial cultural and social themes of the poem and generate the action. ${ }^{23}$

The main problem with both groups of models is, again according to Christian Schneider, the fact that they are still partly based on the modern paradigm of coherence that automatically assumes a bird's-eye perspective of the text as a whole; in other words, a top-down approach. However, this is the perspective of a culture based

20 Schultz, 'The coherence of Middle High German narrative', 84.

21 Schneider, 'Handlung und Handlungslogik', 256. The leading theorist for this group of models is Rainer Warning; see, e.g. R. Warning, 'Erzählen im Paradigma. Kontingenzbewältigung und Kontingenzesposition', Romanistisches Jabrbuch 52 (2001) 176-209.

22 Schulz, Erzähltheorie, 348-50.

23 C. Galatariotou, 'Structural oppositions in the Grottaferrata Digenes Akrites', Byzantine and Modern Greek Studies 11 (1987) 29-68. 
on written texts in their materiality, and, as Schneider notes, it is not a valid starting point for many medieval works, especially those that did not have any material form for most of their recipients, but were received aurally. Schneider suggests that for texts of this type, the notions of both unity (Ganzheit) and closeness (Geschlossenheit) were only relative. ${ }^{24}$ Therefore, both the clear tendency towards episodicity and the medial-pragmatic circumstances for epic poetry speak against the idea that disagreements, gaps and contradictions were a part of an intended, sophisticated narrative technique. ${ }^{25}$ To put it simply, inconsistencies and incongruencies are indisputable facts, but they were not perceived as strongly as they are by a modern reader because medieval narratives developed coherence from the particularity of the episodic narrative.

In the next step, Schneider proposes - instead of searching for one higher-order principle of coherence - to think about structures of mid-range coherence (Kohärenzstrukturen mittlerer Reichweite) governed by three different 'centres of gravity', as he calls them: the schema, the scene and the meaning. ${ }^{26}$ Let us now make some remarks on these centres of gravity and trace them in Digenes G.

\section{Schema}

Schema is, according to Schneider, a standardized course of action based on traditional, preformed plot patterns of varying length, in the case of vernacular narrative poetry with both literary and folk origins. An example of a more extensive schema in western vernacular narratives would be courtship (Brautbewerbung), a shorter one would be the motif of the rash promise.

Probably the most prominent schema in G, occurring in five different variants of varying length, is the abduction of a girl. First, there is the emir's violent, non-consensual abduction of his future wife (1.59-62). Then follows the planned but unimplemented consensual abduction of the same character, now the emir's wife and mother of the small Digenes, to Syria to the emir's mother (2.129-169, including the metaphorical narrative of a dream about a falcon pursuing a dove). Third, there is the consensual abduction of the Girl, accompanied by mutual declarations of love and narrated in detail (4.405-595, with a repeated narration of the same event in 8.6876). In Book 5 follows the story of Haplorrabdes' daughter and her abduction by her seducer - or rather their elopement (5.92-107). Finally, there are two successive unsuccessful attempts at the violent abduction of Digenes' Girl by the raiders (6.130$60,480-650) .{ }^{27}$ Interestingly, the same schema is marginal in ancient novels, but plays

\footnotetext{
24 Cf. the case of alternative endings that also occur in Byzantine vernacular literature, e.g. in the Byzantine Achilleis.

25 Schneider, 'Handlung und Handlungslogik', 256-7.

26 Ibid., 258-9.

27 For variations on the motif in the Russian version, see R. Romanchuk, L. Shelton and R. Goldgof, 'The Old Slavic Digenis Akritis: free retelling or rhetorical translation?', Vestnik of Saint Petersburg University. History 62 (2017) 299-308.
} 
an important role in all three fully preserved Komnenian novels. ${ }^{28}$ It is also common in Modern Greek folk songs. ${ }^{29}$

Other patterns known also in the oral tradition include the motif of the well-guarded daughter and the punished suitors $(4.288-99)^{30}$ and the mother's curse, appearing twice in the poem $(1.70-81 ; 2.89-98) .{ }^{31}$ Hunting scenes also appear more than once. Digenes' first hunting scene (4.102-212) finds a close parallel in the passage of the encounter with the emperor later in the same book (4.1054-78). A parodic variation on this schema, an amusing fight between the hero and his wife, occurs in Ptochoprodromos 1 (155-197). Jeffreys claims that the parallel wording in the two passages of Digenes suggests 'limitations to the material in circulation on Digenes'. ${ }^{32}$ Concerning the passage in Ptochoprodromos, Jeffreys considers the parallel as one of the arguments in favour of the existence of an earlier form of Digenis at the time of the composition of the Ptochoprodromic poems and for its direct influence on the latter work. ${ }^{33}$ However, when we think about this scene as an implementation of a schema, the first case of doubling a scene can be considered a deliberate exploitation of a pattern, and the second case of Ptochoprodromos does not necessarily testify to the author's having drawn on any written version of the poem.

Another important schema stems from Indo-European mythology: the narration about slaying a dragon (6.47-80) finds parallels in the heroic poetry of both East (Iranian epics) and West (the Irish Chúchulainn and the Old English Béowulf), and also in ancient Greek mythology (Herakles and the Lernaean Hydra), Byzantine hagiography, ${ }^{34}$ and the late Byzantine romance ${ }^{35}$ Hagiography displays a further series of smaller and larger schemata that also occur in Digenes. Some were noted by

28 For a thorough analysis of this motif as relevant plot structure, see J. Burton, 'Abduction and elopement in the Byzantine novel', Greek, Roman and Byzantine Studies 41 (2000) 377-409. For a socio-historical analysis of the motif, see A. E. Laiou (ed.), Consent and Coercion to Sex and Marriage in Ancient and Medieval Societies (Washington, D.C. 1993) 199-213. Goldwyn and Nilsson, 'Troy in Byzantine Romances', 194-95, points to the epic-Homeric roots of the abduction schema in G.

29 For some examples comparable to the poem, see R. Beaton, 'Digenis Akrites and Modern Greek folk song: a reassessment', Byzantion 51 (1981) 22-43 (30-2).

30 See Aarne-Thompson-Uther system 310; cf. Jeffreys, Digenis, 85. Cf. also Theodore Prodromos' Rhodanthe and Dosikles 2.175-82.

31 For parallels in Modern Greek folk songs (and several other examples of patterns and their parallels), see Beaton, 'Digenis Akrites and Modern Greek folk song', 35.

32 Jeffreys, Digenis, 131.

33 E. M. Jeffreys, 'The afterlife of Digenes Akrites' in P. Roilos (ed.), Medieval Greek Storytelling (Wiesbaden 2014) 141-59 (147).

34 For some close parallels between G and the Life of Saint Theodore Stratelates, see E. Trapp, 'Hagiographische Elemente im Digenes-Epos', Analecta Bollandiana 94 (1976) 275-87 (280-2). For a thorough psycho-analytical interpretation of the dragon-slaying motif in Digenes, with many parallels, see Livanos, 'A case study in Byzantine dragon-slaying'.

35 E.g. Kallimachos and Chrysorhoe 547-54, ed. M. Pichard, Le Roman de Callimaque et de Chrysorrhoé (Paris 1956). 
Erich Trapp, who was perhaps too keen on finding direct influences from specific texts. ${ }^{36}$ We can also consider early maturity and early signs of unusual accomplishments in the hero (4.66-189), ${ }^{37}$ the lonely life and the gradual move farther and farther from the people $(4.952-64 ; 5.281-9 ; 6.842-8),{ }^{38}$ the exchange of letters with the ruler $(4.971-$ 1000) and paraenesis of the emperor (4.128-46), ${ }^{39}$ and the encounter with a lonely woman in a desert (5.30-54). ${ }^{40}$ The wealth of schemata in common with hagiography shows that oral poetry was not the only, nor the most prominent, source of inspiration for Digenis G.

Let me close this section with a short remark on the bipartite structure of the poem and its tendency to double motifs and scenes, something that has been commented on many times. ${ }^{41}$ The doubling occurs both between the two parts and within each of them. In each part the hero abducts his future wife, leaves his family, or slays a lion. In the first part, we can follow the doubled motif of a mother's curse contained in a letter. In the second part, for instance, the motif of the hunt or the hero's adultery occur twice. It is known that the bipartite structure is characteristic also of almost all late Byzantine romances, ${ }^{42}$ but it is also one more feature that connects Digenes with western narratives. ${ }^{43}$ In the context of schemata, it is of interest to mention the 'double course' model (doppelter Kursus or Dopplewegstruktur), included by Armin Schulz in his list of the most common medieval narrative schemata. ${ }^{44}$ It has been proposed by Hugo Kuhn for the German version of Erec and Enide. ${ }^{45}$ Kuhn showed that in addition to a clear division into two main parts, Hartmann's Erec is also characterized by a series of doubled motifs, which can at first sight be perceived as a sign of clumsiness, but which actually reflects systematic intention and is the key to understanding the meaning of the entire narrative. This approach could be fruitful also for Digenes $G$ and I will explore its potential in the next section.

36 Trapp, 'Hagiographische Elemente'.

37 For some examples from hagiography, see T. Pratsch, Der hagiographische Topos (Berlin 2005) 88-92.

38 Obvious examples include the Life of Antony (11-13 and 49-53) and the Life of Lazaros of the Mount Galesion; see M. Veikou, 'Space in texts and space as text: a new approach to Byzantine spatial notions', Scandinavian Journal of Byzantine and Modern Greek Studies 2 (2016) 143-75.

39 Cf. Life of Antony 81, ed. G. J. M. Bartelink, Athanase d'Alexandrie, Vie d'Antoine (Paris 2004).

40 For a comparison with a very similar motif, again in the Life of Lazarus, see A. P. Kazhdan, 'Hagiographical notes (suite)', Byzantion 54 (1984) 176-92 (180-2).

41 See, e.g. R. Beaton, The Medieval Greek romance (2nd edn., London) 32; G. Kastner, 'Narrative unity in the Digenes Akrites', in J. W. Baker (ed.), Second Annual Byzantine Studies Conference, University of Wisconsin: Abstracts (Madison 1976) 35-36.

42 Beaton, Medieval Greek Romance, 117-29.

43 See W. Ryding, Structure in Medieval Narrative (The Hague 1971) 25-7, 117-35.

44 Schulz, Erzähltheorie, 245-50.

45 H. Kuhn, 'Erec', in Kuhn, Dichtung und Welt im Mittelalter (2nd edn., Stuttgart 1969) 126-40. 


\section{Scene}

The second centre of gravity proposed by Schneider is the scene, an impressive representation of a single event, elaborated in detail even at the expense of the whole. ${ }^{46}$ In such cases, the author or redactor gives priority to the effectiveness of a scene, which enables achievement of a visual or acoustic effect and facilitates the recipient's immersion in the illusion of reality. On the other hand, such elaborated scenes can also emphasize the overall intention of the work. Schneider underscores that such scenes often include features of everyday life and established cultural rituals, such as gestures, symbols and ceremonials (in contrast to the purely literary schemata listed in the previous part).

The passage in Book 6, presented above as an example of multiple inconsistencies, actually consists of a series of such elaborated scenes to which Schneider draws our attention, and the focus on detail is precisely what causes the inconsistencies. Let us examine a couple of them again from this point of view.

6.109-25: The main aim of this scene is to offer a vivid impression of the Girl's beauty and an acoustic idea of her voice, re-echoed by the hills, which impressed the passing apelatai. It is the first time in $G$ that the three leaders of the raiders enter the scene, so the indication of their names emphasizes their importance as characters and improves the clarity of the text. The verisimilitude is further augmented by naming the road (Trosis), explaining the nom parlant (117-18: the place where many were badly wounded $)^{47}$ and providing an estimate of the distance (124: a mile).

6.126-56: The essence of this scene is Digenes defeating a superior force, and that is why the number of the apelatai suddenly and seemingly for no reason grows. It is also yet another occasion to emphasize one of Digenes' characteristic features: his solitude (129-

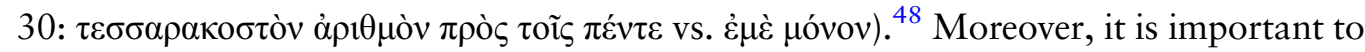
justify the fright of the Girl (134-8) and to give Digenes occasion to calm her (142-3). The particular scene of the fight covers verses 146-56. With verse 157 begins the successive scene of Digenes' dialogue with the Girl: at this moment, the focus of the narrator is no longer on battle, and, from his point of view, it is no longer very important whether Digenes throws down his staff (as would be consistent with the previous scene) or his sword (as in 157). Moreover, casting down of the sword has a knightly element which would probably be less clear if the more primitive staff featured.

My suggestion is that the main focus of both the redactor and the recipients was on the aim of these scenes: first, to bring on to the stage the apelatai enchanted by the Girl's beauty and voice; second, the hero prevailing over even more opponents; third, the dialogue between Digenes and the Girl. This shifting of focus from the whole to the 
particular scene does not, of course, erase the inconsistencies, but it can explain why they were not perceived as problematic.

Let us now look more closely at the double combat of Digenes and Maximou and explore whether it is, in fact, a narrative need that causes the doubling of the scene. The scene preceding the first clash (6.546-80) presents Maximou's splendid appearance that differentiates her from the other leaders (546-56), her boastful nature (564-7), Digenes' courtesy (569-71), his fight with the turbid river (570-6), Maximou's noble reaction to this (577-8), and the villainous response of her men (579-80). After a short scene containing Maximou's unsuccessful attack and Digenes' turning his strength against her horse (581-9), Maximou begs for mercy and he turns on her men (595). He routs them all (610-17) and subsequently beats the four apelatai (617-42). By the end of this passage, there are enough free horses that Digenes can catch one of them and give it to Maximou in exchange for the one he slayed (682).

As we have seen, the defeat of Maximou is only a small part of Digenes' combat triumph, and for all of its stages extras and spectators are necessary. Simultaneously, this is only a prelude to the key scene of the entire part: the second duel with Maximou on the next day (740-76) and the subsequent adultery (777ff - here follows the famous lacuna in the $G$ manuscript ${ }^{49}$ ). This consensual and sinful sexual act excludes extras and spectators. It may well be that the narration is based on two alternative versions of one event and that it draws on literary models, as Dyck has suggested. What I question is Dyck's claim that the plot and the characterization of Maximou suffer from the way in which the redactor organizes the narrative. ${ }^{50}$ In my view, the plot is constructed consistently with the aims of the narrative: the first combat is part of a more extensive scene presenting Digenes' bravery and nobility; the second combat, in contrast, presents his moral weakness and sinfulness. ${ }^{51}$ Moreover, these aims are explicitly articulated by the narrator in a passage set between his first and second clash with Maximou (600-6):

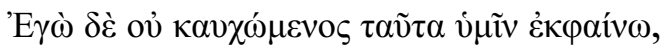

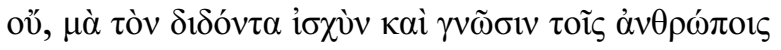

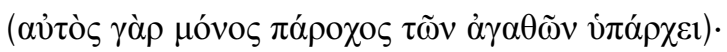

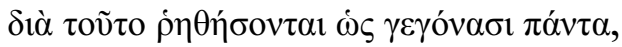

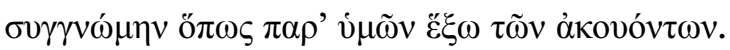

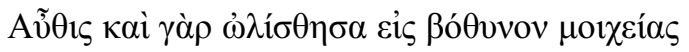

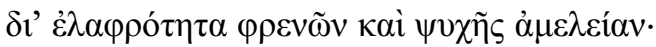

But I do not tell you of this as a braggart, no, by Him who gives strength and knowledge to men (for it is He alone who provides good things). 
For this reason everything will be told as it happened, so that I may be pardoned by you, my audience.

For once again I slipped into the pit of adultery, through weakness of mind and spiritual neglect.

Digenes is aware of his own bravery, but also of the fact that it is not to his own credit, but to God's. The main aim of the passage, as the redactor of $G$ presents it, is to tell a tale of weakness of will and sin, a counterpart to the first adultery in Book 5 (5.235-56). ${ }^{52}$

Moreover, Dyck's objections to the contradictory characterization of Maximou may be justified from a modern point of view. But it is good to keep in mind that the characters in medieval narratives build coherence through their intentions, actions, and reactions on specific occasions and therefore can seem to a modern reader as psychologically flat. ${ }^{53}$ For precisely this reason, character is not proposed by Schneider as a centre of gravity in medieval narratives. ${ }^{54}$

\section{Meaning}

It has often been noted that one of the prominent characteristic features of many medieval narratives is a kind of fragmentation. They seem to be built up of individual narrative elements that create an inconsistent whole, yet they produce a meaningful unit, if vertical-paradigmatic relations are emphasized rather than horizontal-syntagmatic ones. Within the frame of the last centre of gravity, we seek the (figurative or symbolic) meaning. What do the individual motifs stand for? What do they mean for the narrative? ? $^{55}$

In the passage discussed above, we have already encountered some important themes that occur in Digenes multiple times and in various representations: love, abduction, nobility and loneliness form part of a broader topic of family relations; nobility is closely connected to bravery. These themes are often represented in the structural oppositions recognized by Galatariotou (house and tent, male and female, honour and shame). ${ }^{56}$ James Trilling has suggested, by contrast, that Digenes is a cautionary tale of human weakness. ${ }^{57} \mathrm{I}$ have already tried to show how the doubling of scenes and motives contributes to resolving the meaning, with the example of the doubled scene with Maximou, the first scene featuring bravery and nobility, the second moral weakness.

Another method of highlighting meaning is the use of signal words that are used for structuring proposes and building a conceptual network. As Monika Fludernik puts it,

52 For a thorough comparison of these two passages, see Galatariotou, 'Structural oppositions', 59-62.

53 See e.g. P. K. Philipowski, 'Figur - Mittelalter / Character - Middle Ages', in E. von Contzen and S. Tilg,

Handbuch historische Narratologie (Berlin 2019) 116-28.

54 Schneider, 'Handlung und Handlungslogik', 258.

55 Ibid., 259.

56 Galatariotou, 'Structural oppositions'.

57 Trilling, 'Re-introducing Digenis Akritis'. 
The web of recurring mentions and repetitions gives rise to a kind of symbolism, which ... functions metonymically: a sequence of key ideas is associated with particular characters and situations. ... Similarities are to be expected as the ideas stem from word repetition or are drawn from the same word fields. They are not exploited to create sensory impressions, but are used, instead, to generate arguments, contrasts and interpretations: in other words a conceptual network of meaning is created on a higher level. ${ }^{58}$

The noticeable example of repeating the word $\mu$ óvos ('alone') was already mentioned. Another prominent example is the name of the hero itself with the distinctive component

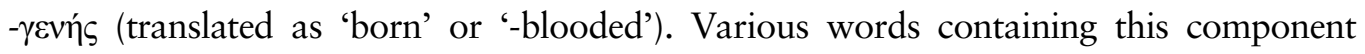

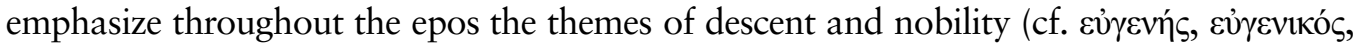

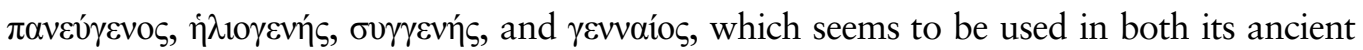
meaning, 'noble', and the later one, 'brave'). Moreover, we can follow consistent wordplay connecting the two just mentioned examples of signal words: the paradox of

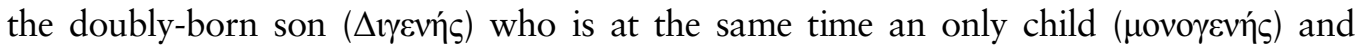

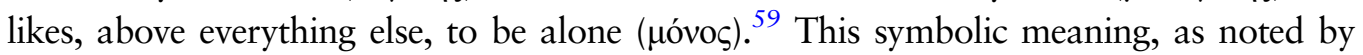
Roderick Beaton, even touches on the mystical in the implied reference to Christ, the Only Begotten Son. ${ }^{60}$ Similarly, speaking names, often doubled and used for two different places (as the above-mentioned Trosis or Blattolivadin) can bear meaning. ${ }^{61}$

Another means of helping the audience to find order in the labyrinth of non-causally linked, often doubled episodes is narratorial comments, which determine the character of the narration in the $G$ version to the extent that they can be considered a prominent mark of its style. If we follow Seymour Chatman's categorization of narrative comments into two main groups - commentary on the story and commentary on the discourse -, we detect that the latter type occurs rather rarely (for an example, see 600-6 cited above). On the other hand, the redactor leads the audience through longer or shorter story-oriented comments that foreshadow the story and its message. The majority of them can be sorted into two groups, again according to Chatman's categorization: generalizations and judgements. ${ }^{62}$ Generalizations speak mostly about the power of love and its influence on human lives, which is most explicitly stated in the prologue of Book 4 (4.6-18) and frequently alluded to in a series of story-oriented comments:

58 M. Fludernik, An Introduction to Narratology (New York 2009) 76-7.

59 Cf. G 6.288-91.

60 R. Beaton, 'Was Digenes Akrites an oral poem?', Byzantine and Modern Greek Studies 7 (1981) 7-27 (17-21).

61 For a thorough analysis of proper names in G, see O. Cikán and M. Kulhánková, 'Die Welt des Digenes Akrites. Zu den Eigennamen in der Grottaferrata-Version unter Berücksichtigung historischer Schichten und literarischer Associationsmöglichkeiten', Byzantinoslavica 78 (2020) 240-61.

62 See S. Chatman, Story and Discourse: narrative structure in fiction and film (Ithaca 1978) 228-53. The third type of story-oriented comment according to this categorization is interpretation, an utterance providing explanation of circumstances or additional information, see e.g. 1.115; 4.1068. 


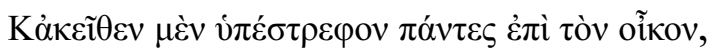

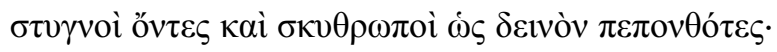

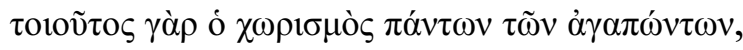

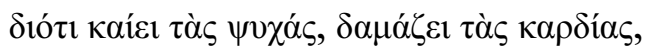

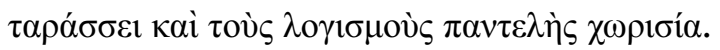

And from that point they all returned to the house, downcast and gloomy, as if they had suffered a dreadful blow.

For such is separation for all who love, because souls are seared, heard subdued and reason confused by complete separation. ${ }^{63}$

In the group of judgements, moralizing apophthegmatic expressions commenting on the knightly values of a proper Christian and warrior are predominant:

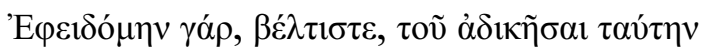

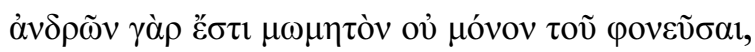

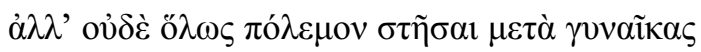

I avoided harming her, my good friend, for it is a reproach to men not only to kill women but even to start fighting with them. ${ }^{64}$

Such moralizing statements occur also in direct speech, mostly by the hero himself. ${ }^{65}$ Some are marked in the manuscript and many of them, as Paolo Odorico has showed, stem from or find analogues in gnomological literature. ${ }^{66}$ In contrast to Digenes' acts, the message of the comments appears to be consistent, repeatedly emphasizing knightly values and God's power. Thus, although the narratorial comments might seem awkward to the modern reader, I would like to suggest that we - instead of reproaching them for being clumsily pasted in ${ }^{67}$ or for removing the present version from its epic roots ${ }^{68}$ - perceive them as part of the specific narrative strategy of $G$, contributing to the overall coherence of meaning of the poem, although filled with inconsistencies on the plot level.

\section{Towards a shift in the perception of coherence}

My aim here has not been to offer yet another 'quality assessment' of Digenes G, nor to persuade the reader that what we perceive as inconsistencies and oddities is, in fact,

63 3.32-6. Cf. also 2.45-6, 109, 285; 3.81-2, 285-6; 4.276-7, 342-6, 525-31.

64 6.748-750. Cf. also 1.192; 3.18; 6.421-2, 598-9.

65 E.g. 4.661-662. 748-749.1030; 6.143

66 See P. Odorico, 'La Sapienza del Digenis: materiali per lo studio dei loci similes nella recenzione di Grottaferrata', Byzantion 59 (1986) 137-63; and Jeffreys, Digenis Akritis, xix and xlii-xliv.

67 Dyck, 'The taming of Digenes', 299-300.

68 So Ricks, 'Digenis and Maximou', 325. 
perfectly consistent and impeccably coherent. However, the reading of poems such as the Nibelungenlied, abounding in parallels and grappling with similar coherence issues, invites us to compare Digenes $\mathrm{G}$ with contemporary western narrative poetry rather than with the Komnenian novels or other Byzantine texts. Important steps in this direction, with fruitful results, have already been made by Alexiou, ${ }^{69}$ and especially by Fenik; ${ }^{70}$ both, however, focused on the E version of Digenes. The recent study by Trilling looked to the West for thematic connections, and even for possible inspiration. ${ }^{71}$ Prompted by advances in historical narratology, especially of the German school, I found it worthwhile to look for analogous principles and models of coherence in Digenes G. Following Schneider's proposal to seek structures of midrange coherence, governed by three different 'centres of gravity', I have attempted to trace a series of schemata that frame the narrative tradition in which the poem moves. Focusing on elaborated scenes and appreciating their effectiveness and function could overshadow the inconsistencies in plot logic in the eyes of contemporary audience. Repetitions of schemata and scenes, seemingly unnecessary and senseless from the modern point of view, can feature a series of variations in details which lead to completely different functions of the same narrative structure repeated two or more times. Moreover, the use of signal words and narratorial comments may be understood as contributing to the hierarchical organization of the narrative, leading the recipient to figure out the symbolic meaning of the narrated events.

The analysis pursued above is certainly selective and focuses on only a few passages of the poem. Despite this limitation, I hope to have shown that re-examining of a text such as Digenes with the help of recent findings of historical narratology - in this case concerning the issue of coherence - may be worthwhile. Even if it does not change our approach to the text entirely, it can help us to refine our understanding of the functions and effects of the narrative for the contemporary audience.

Markéta Kulhánková is Associate Professor in Classical Philology at Masaryk University in Brno, Czech Republic, where she teaches Byzantine and early Modern Greek literature, theory of literature and Modern Greek language and culture. Her research focuses mainly on Byzantine narrative, both in verse and in prose. She is also interested in the reception of Byzantium in modern culture and translates Byzantine and Modern Greek literature into Czech.

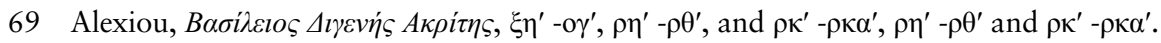

70 Fenik, Digenis.

71 Trilling, 'Re-introducing Digenis Akritis'. 